\title{
Critical Thinking in College Freshmen: The Impact of Secondary and Higher Education
}

\author{
Marie Evens ${ }^{1}$, An Verburgh ${ }^{1} \&$ Jan Elen $^{1}$ \\ ${ }^{1}$ Centre for Instructional Psychology and Technology, KU Leuven, Belgium \\ Correspondence: Marie Evens, Centre for Instructional Psychology and Technology, KU Leuven, Belgium, \\ Dekenstraat 2, postbox 3773. E-mail: marie.evens@ppw.kuleuven.be
}

Received: July 1, 2013

Accepted: August 5, 2013

Online Published: August 6, 2013

doi:10.5430/ijhe.v2n3p139

URL: http://dx.doi.org/10.5430/ijhe.v2n3p139

\begin{abstract}
Critical thinking helps students to confront a multitude of challenges they will face in their carreers and personal lives. It is therefore an important task of higher education to promote students' critical thinking. However, students do not enter higher education as a blank slate. Background characteristics of students are important in developing instruction. The present study investigates the influence of an important background characteristic, namely students' secondary education, and their current higher education programme on critical thinking in the first year of higher education. The critical thinking of college freshmen was measured by the Scipio, a test consisting of both constructed response items and forced choice items. The results indicate that (1) the growth in critical thinking during the first year of higher education is on average small, (2) students with a background in general secondary education have higher entrance performances and show more growth during the first year than students with other educational backgrounds, (3) critical thinking plays a role in the educational choice that students make when they enter higher education, and (4) students in a professional bachelor programme grow more in CT during the first year of higher education than students in an academic bachelor programme.
\end{abstract}

Keywords: Critical thinking, Prior education, Higher education, Secondary education, Field of study, Educational choice

\section{Introduction}

Critical thinking (CT) is generally recognized to be an important educational goal (Halpern, 1998; Ku, 2009; Tsui, 2002). It helps students to confront a multitude of challenges they will face in their personal lives and careers (Halpern, 1998; Tsui, 2002). Furthermore, it encourages them to become independent lifelong learners (Tsui, 2002). 'To be critical' and 'to think critically' are important requirements of our Western culture (ten Dam \& Volman, 2004). Modern citizens should be able to make thoughtful choices and respect the choices and opinions of others. They are expected to communicate about disagreements, thereby forming their own opinion and making it public (ten Dam \& Volman, 2004). It is important for all disciplines and levels of education to prepare individuals to think well and to think for themselves (Pithers \& Soden, 2000). Not surprisingly, CT is part of the cross-curricular attainment targets of secondary education (SE) in Flanders, Belgium (Ministry of the Flemish community, 2005). Furthermore, the development of CT is an important and recurrent aim in Flemish higher education (HE) programmes and courses (Verburgh, Schouteden \& Elen, 2012).

\subsection{Definition of CT}

Several authors have constructed a definition of CT (Bailin, Case, Coombs \& Daniels, 1999). According to Halpern (1998, 1999), CT is the kind of purposeful, reasoned and goal-directed thinking that one needs in order to solve problems, make decisions, formulate inferences and calculate likelihoods. Similarly, a panel of CT experts defined $\mathrm{CT}$ as reasonable and reflective thinking that is focused on the decision of what to believe or what to do (Facione, 1990).

Although there is no absolute agreement about the meaning of CT, there is consensus among researchers that CT consists of both skills and dispositions (Halpern, 1999, 2007; Ku \& Ho, 2010). The expert panel in Facione (1990) emphasized the following CT skills: interpretation, analysis, evaluation, inference, explanation, and self-regulation. Halpern (1998) constructed a taxonomy of five categories of CT skills: reasoning skills, argument analysis skills, skills in thinking as hypothesis testing, likelihood and uncertainty, and decision-making and problem-solving skills. 
Skills in CT determine how well an individual is able to tackle a thinking task, while dispositions affect the way in which one approaches the task. The disposition towards CT allows a person to recognize when a certain skill is required and to apply this skill (Ku \& Ho, 2010). The most important dispositions to CT are, according to Halpern (1998): willingness to engage in and persist at a complex task, habitual use of plans, suppression of impulsive activity, flexibility, open-mindedness, willingness to abandon nonproductive strategies in an attempt to self-correct, and an awareness of the social realities that need to be overcome so that thoughts can become actions.

\subsection{CT in $H E$}

Several researchers have studied the growth of CT in higher education (HE). CT performances of beginning and more advanced students in cross-sectional or longitudinal studies were compared. Most of the researchers found that CT grows during HE and that the largest part of the growth takes place in the first two years (Arum \& Roksa, 2011; Astin, 1993; Bers, McGowan \& Rubin, 1996; Giancarlo \& Facione, 2001; Hagedorn et al., 1999; Lehmann, 1963; McMillan, 1987; Miller, 1992).

However, Bok (2006) pointed out that the established growth in CT in most studies is rather limited. Similarly, Arum and Roksa (2011) drew attention to the fact that, in their study, a significant proportion of students showed no growth at all. Pascarella, Blaich, Martin and Hanson (2011) replicated Arum and Roksa's study, found closely matching results and concluded that Arum and Roksa's findings should be taken seriously. Arum and Roksa attributed the overall limited growth in CT to students becoming more and more academically adrift. Studying is no longer a priority for students. The culture among students in HE institutions encourages them to achieve as much as possible with minimal effort, and as a consequence to choose courses that do not promote CT. Furthermore, Arum and Roksa conclude that universities do not pay enough attention to teaching in general. Similary, Bok (2006) stresses the gap between what researchers consider important and the behavior of people in a teaching position. A remark should be made here; Arum and Roksa and Bok focus on the situation in the USA. Their conclusions are not necessarily valid for education around the world and more specifically the Flemish situation because of the differences in educational systems. Flemish students have for instance mostly mandatory courses and as a consequence cannot opt for courses that may or may not promote CT.

The differences in CT between different majors in HE have been studied several times, leading to conflicting results (Arum \& Roksa, 2011; Astin, 1993; Erwin \& Sebrell, 2003; Gadzella \& Masten, 1998; Giancarlo \& Facione, 2001; Li, Long \& Simpson, 1999; Terenzini, Springer, Pascarella \& Nora, 1995). It is not clear from the research literature what major in HE leads to the best CT performance.

\subsection{Prior education and $C T$}

The research literature claims that CT can be taught and learned (Halpern, 1998). Several studies have sought for the best teaching strategies to promote students' CT, leading to different results (Halpern, 1998; Paul, 1992; Tsui, 2002). However, CT instruction in HE should take into account students' initial situation as students do not enter HE with a blank page (Arum \& Roksa, 2011). Their entrance characteristics play an important role in student learning (Pascarella \& Terenzini, 2005). One of these characteristics is prior education.

To the best of our knowledge, the influence of prior education on $\mathrm{CT}$ in HE has not yet been investigated. Because CT is related to academic performance in HE (Miller, Sadler \& Mohl, 1993; Scott \& Markert, 1994; Scott, Markert \& Dunn, 1998) it is expected in the present study that students with more academic prior education will also perform better on CT.

Before drawing attention to literature about the relation between fields of study in SE and academic performance in Flanders, some information on the Flemish education system is necessary. In Flanders there are no central examinations that enable mapping end capabilities in SE and predicting academic performance (Janssens \& De Metsenaere, 2000). In Flemish SE pupils can choose between four education forms and within each form pupils choose one of the different fields of study. General SE provides broad general education, which prepares pupils for HE. Examples of fields of study in this education form are classical languages, mathematics, sciences, economics and human sciences. Technical SE consists of general and technical/theoretical subjects. Pupils are prepared to exercise a profession or pass on to HE. Artistic SE provides the combination of a broad general education and active art education. After artistic SE, pupils are prepared to exercise a profession or go on to HE. Finally, vocational SE provides practice-oriented education. The aim is to learn a specific profession in addition to receiving general education. After finishing SE a pupil receives a certificate. Every certificate of SE provides unrestricted access to Flemish HE, which is organized according to the bachelor-master structure. Higher professional education only offers bachelor programmes. Higher academic education consists of bachelor and master programmes (Ministry of 
the Flemish Community, 2005).

Flemish research shows that students' SE influences their academic performance in HE (Bellens, 2010; Janssens \& De Metsenaere, 2000; Lacante et al., 2001; Smedts, Van Landeghem \& Van Damme, 2011). Lacante et al. (2001) examined the relation between SE and academic skills, measured by the Learning And Study Strategies Inventory (LASSI) and found general SE pupils outperformed the other education forms. Within general SE the best results were obtained by mathematics and classical languages pupils and the lowest results by human sciences pupils. The latter showed a profile of academic performance in HE similar to that of technical SE pupils. Several studies found a relation between SE and success rates in HE (Bellens, 2010; Deprez, 2003; Janssens \& De Metsenaere, 2000; Rombaut, 2006). More specifically, these studies showed that within general SE students from classical languages and mathematics had the highest success rates en students from human sciences had the lowest success rates. Smedts et al. (2011) found that students with an general SE certificate had a greater chance of obtaining a bachelor's degree than other students. Students with a vocational SE background had the lowest chance.

\subsection{The present study}

Because the research literature shows that both students' SE and HE play an important role in several study-related variables in HE, (Astin, 1993; Bellens, 2010; Cooper et al., 2008; Deprez, 2003; Erwin \& Sebrell, 2003; Gadzella \& Masten, 1998; Giancarlo \& Facione, 2001; Janssens \& De Metsenaere, 2000; Lacante et al., 2001; Li, Long \& Simpson, 1999; Smedts et al., 2011; Terenzini, Springer, Pascarella \& Nora, 1995), the present study will investigate the relation between on the one hand students' $\mathrm{CT}$ in $\mathrm{HE}$ and on the other hand their prior and current education.

Furthermore, it is not clear from the literature how much students grow in CT during the first year of HE. Most research on the growth of $\mathrm{CT}$ in $\mathrm{HE}$ only looked at average growth scores of a whole sample of students. Evidence on differences between groups of students is scarce. Arum and Roksa (2011) reported that a significant proportion of students in their study showed no growth at all. It is however unclear why exactly these students did not grow in CT. Therefore the present study also examines whether differences in growth of CT can be attributed to educational choice in both SE and HE.

A possible framework from which differences in growth scores can be viewed is the Matthew effect (Matthew 25:29). This effect refers to the phenomenon where the rich get richer and the poor get poorer (Stanovich, 1986). Applied to education, the Matthew effect implies that early achievement produces faster rates of subsequent achievement (Walberg \& Tsai, 1983). If the Matthew effect would apply in the context of the present study, then a greater development in CT could be expected from students with an educational background that contributes to an initially strong performance, i.e. students with a more academic prior education.

The majority of research on CT development is Anglo-Saxon, which may cause the results of prior research to be specific to this area. In Flanders, no research has been conducted on the growth of CT in HE. The present study will focus on the Flemish situation.

Because of the above mentioned gaps in the knowledge about $\mathrm{CT}$ the following research questions are posed:

Research question 1: Do students grow in CT during the first year of HE?

Research question 2: What is the impact of SE and HE on CT in the first year of HE?

a. Are there differences in entrance performance based on SE and HE?

b. Are there differences in growth based on SE and HE?

c. Are there differences in end performance based on SE and HE?

\section{Method}

\subsection{Participants}

This study is part of a large-scale research project on the CT of students enrolled in a bachelor or master program at a Flemish university or university college. Students were tested both at the beginning (November administration) and at the end (May administration) of the academic year. In total 831 first year students participated at least once. 753 first year students took part in the November administration. 410 students took part in the May administration. A total of 332 first year students participated in both administrations.

The total sample $(N=831)$ consists of slightly more girls $(52 \%)$ than boys $(48 \%)$. The average age is 19.50 years with a standard deviation of .98. The youngest participant is 17 years old an the oldest is 25.103 participants did not fill in their age. The majority of the participants studied an academic field of study in SE (57\%). 40\% has a technical SE background. The two least represented education forms are artistic SE (.7 \%) and vocational SE $(2.5 \%)$. 


\subsection{Instruments}

To measure CT the Scipio was used (Verburgh, François \& Elen, 2012). This is a Dutch test based on the Cornell Critical Thinking Test (CCTT) and the Halpern Critical Thinking Assessment (HCTA, Halpern, 2007). The Scipio consists of 17 situations with both constructed response items and forced choice items. Two situations were based on the 'meaning and fallacies' and 'identification of assumption' scales of the CCTT (Ennis, Millman \& Tomko, 2005). The other items are taken from the HCTA. The test starts with an example situation, three example questions and possible answers to make participants familiar with the instrument. There also are some questions on background information, namely date of birth, sex, field of study, institution, year of study and grade retention in HE, education form and field of study in SE and language proficiency.

The maximum score that can be obtained on the Scipio is 95. The maximum score differs per item, ranging between one and ten. The answers on the constructed response items were graded with an elaborated scoring key. Inter-rater reliability is high; ranging between .70 and .98 (Verburgh, Francois, Elen \& Janssen, 2013). Maximum scores for the forced choice items vary between one and ten.

\subsection{Procedure}

Participants completed the test twice. Test administrations took place in the participating HE institutions. Students were asked to fill in the Scipio during lecture time. They had one hour to complete the test. Mostly the test was taken digitally. In one institution a paper version was administered. Participants were requested to fill in their name, which made it possible to link the November and May administrations of the same participants to each other and calculate difference scores. However, data analysis was anonymous.

\subsection{Data analysis and expectations}

For the first research question a paired samples t-test is used. A limited growth in CT during the first year of HE is expected.

The dependent variables of research question $2 \mathrm{a}, \mathrm{b}$ and $\mathrm{c}$ are respectively the November, May and the growth scores on the Scipio. All three dependent variables are approximately normally distributed. Boxplots were used to detect outliers in the samples. Outliers were defined as those cases that differ more than three standard deviations from the mean (Field, 2005). After removing the outliers, 752 participants remain in the November sample, 398 in the May sample and 327 in the growth sample.

The independent variables can be divided into two groups; namely SE and HE. For SE two variables were used: education form and fields of study (see Table 1). The total number of fields of study in SE is high. Therefore the fields of study were aggregated into categories, based on research of Bellens (2010), Deprez (2003), Janssens \& De Metsenaere (2000), Lacante et al. (2001), Smedts et al. (2011) and Hermans, Opdenakker and Van Damme (2003). Because of the small amount of students in the vocational SE and artistic SE groups, only a comparison between the education forms general SE and technical/artistic SE was made. Concerning HE, two independent variables are used, namely 'discipline' and 'programme type'. Firstly, the disciplines 'sciences' and 'humanities' were compared, based on the respective difference between 'hard' sciences and 'soft' sciences (Biglan, 1973). Second, the distinction between professional and academic programme types was used.

For the second research question a three-way ANOVA was used, which made it possible to study both main and interaction effects. For each of the three parts of research question 2 ( $a, b$ and $c)$ two analyses were performed. Both analyses consisted of one dependent variable (respectively the November scores, the growth scores and the May scores) and the independent variables programme type and discipline in HE. The third independent variable varied in both analyses. The first analysis included education form in SE, while the second analysis included field of study in SE.

According to the literature, it is expected that there will be differences in entrance performance on CT based on both education form and field of study. More specifically, students with an general SE background are expected to outperform students with a technical/artistic background. Students with a prior education of classical languages and/or mathematics as field of study are expected to outperform other academic fields of study in SE, especially human sciences. Furthermore, differences in CT growth during the first year of HE according to both prior and current education are expected. According to the Matthew effect, students with a high entrance performance are expected to show a larger growth than students with a low entrance performance. As a consequence, higher end performances are expected from students with a more academic prior education. 
Table 1. Composition and frequencies of educational forms and fields of study in SE $(N=823)$

\begin{tabular}{|c|c|c|c|}
\hline $\begin{array}{l}\text { Educational forms } \\
\text { Fields of study }\end{array}$ & $n$ & $\%$ & Composition \\
\hline General SE & 445 & 53.5 & All academic fields of study \\
\hline $\begin{array}{l}\text { Academic - classical languages and } \\
\text { mathematics }\end{array}$ & 26 & 3.1 & Latin - mathematics, Greek - mathematics \\
\hline Academic - classical languages & 66 & 7.9 & $\begin{array}{l}\text { Greek - Latin, Latin - modern languages, Latin - } \\
\text { sciences }\end{array}$ \\
\hline Academic - mathematics & 128 & 15.4 & $\begin{array}{l}\text { Sciences - mathematics, economics - mathematics, } \\
\text { modern languages - mathematics }\end{array}$ \\
\hline Academic - human sciences & 76 & 9.1 & Human sciences \\
\hline Academic - rest category & 128 & 15.4 & $\begin{array}{l}\text { Economics - modern languages, modern languages - } \\
\text { sciences, sports sciences }\end{array}$ \\
\hline Academic - not specified & 21 & 2.5 & $\begin{array}{l}\text { All participants who only filled in general SE, but no } \\
\text { specific field of study }\end{array}$ \\
\hline Technical/artistic SE & 311 & 37.4 & All technical/artistic fields of study \\
\hline Technical/artistic - preparing for HE & 77 & 9.3 & $\begin{array}{l}\text { Industrial sciences, biotechnical sciences, technique - } \\
\text { sciences }\end{array}$ \\
\hline $\begin{array}{l}\text { Technical/artistic - preparing for labor } \\
\text { market }\end{array}$ & 130 & 15.6 & $\begin{array}{l}\text { Accounting - informatics, chemics, trade, social and } \\
\text { technical sciences, power electronics, } \\
\text { electromechanics, physical education and sports, } \\
\text { reception and public relations, secretary - languages, } \\
\text { applied visual arts, free visual arts, hotel, health and } \\
\text { wellbeing sciences, youth and disabled care, beauty } \\
\text { care, optics techniques }\end{array}$ \\
\hline Technical/artistic - not specified & 104 & 12.5 & $\begin{array}{l}\text { All participants who only filled in technical/artistic SE, } \\
\text { but no specific field of study }\end{array}$ \\
\hline Vocational SE & 19 & 2.2 & All vocational fields of study \\
\hline Education form unknown & 48 & 6.7 & $\begin{array}{l}\text { All participants who did not fill in their education form } \\
\text { or field of study }\end{array}$ \\
\hline
\end{tabular}

\section{Results}

\subsection{Research question 1: Does a growth in CT occur during the first year of HE?}

The average growth in CT between the November and the May administration is 1.80 points with a standard deviation of 6.83 (see Table 2). The results of the paired samples t-test indicate that this result is significant, $t=-4.76$, $p<.001$. Cohen's $d$ is -.53 , indicating a medium effect size.

Table 2. Descriptive statistics of the dependent variables

\begin{tabular}{llllll}
\hline & $N$ & Minimum & Maximum & $M$ & $S D$ \\
\hline November & 752 & 27 & 73 & 50.18 & 8.09 \\
May & 398 & 31 & 73 & 52.20 & 8.33 \\
Growth & 327 & -16 & 22 & 1.80 & 6.83 \\
\hline
\end{tabular}

3.2 Research question 2: What are the effects of SE and HE on CT in the first year of HE?

a. Are there differences in entrance performance based on SE and HE?

The mean score on CT in November is 50.18 with a standard deviation of 8.09 (see Table 2). In the first analysis, which consists of the independent variables education form in SE and the two HE variables, a significant main effect of education form on CT is found, $F(1,719)=15,86, p<.001$. Students with an academic background in SE $(M=$ $51.88, S D=.83)$ significantly outperform students with a technical/artistic SE background $(M=47.94, S D=.53)$. There are no other significant main or interaction effects found.

In the second analysis, consisting of the independent variables field of study in SE and the two HE variables, one main effect and one interaction effect are found. Firstly, field of study in SE has a main effect on entrance CT performance, $F(8,680)=2.01, p<.05$. The Tukey post hoc test revealed that students with a prior education in 
general SE - classical languages - mathematics $(M=55.48, S D=1.95)$, general SE - classical languages $(M=56.23$, $S D=2.21)$, general SE - mathematics $(M=51.59, S D=1.62)$, general SE - human sciences $(M=51.15, S D=2.64)$ and general SE - rest category $(M=50.28, S D=1.64)$ significantly outperform students from technical/artistic SE preparing for the labour market $(M=49.04, S D=1.14)$. Furthermore, students from general SE classical languages significantly outperform students with a prior education in technical/artistic SE - not specified $(M=48.84, S D=.92)$. The differences between the other fields of study are not significant.

Secondly, there is a significant interaction effect between field of study in SE and discipline in HE on entrance CT performance, $F(8,680)=2.03, p<.05$ (see Figure 1). This indicates that the influence of discipline in HE on CT is different based on prior education. More specifically, students in the exact sciences outperform the humanities if they studied general SE - classical languages, general SE - mathematics, general SE - human sciences, technical/artistic $\mathrm{SE}$ - preparing for the labour market or technical/artistic SE - not specified. On the other hand, students in the humanities outperform the exact sciences if they have an educational background in general SE - classical languages and mathematics, general SE - rest category or technical/artistic SE - preparing for higher education (see Table 3).

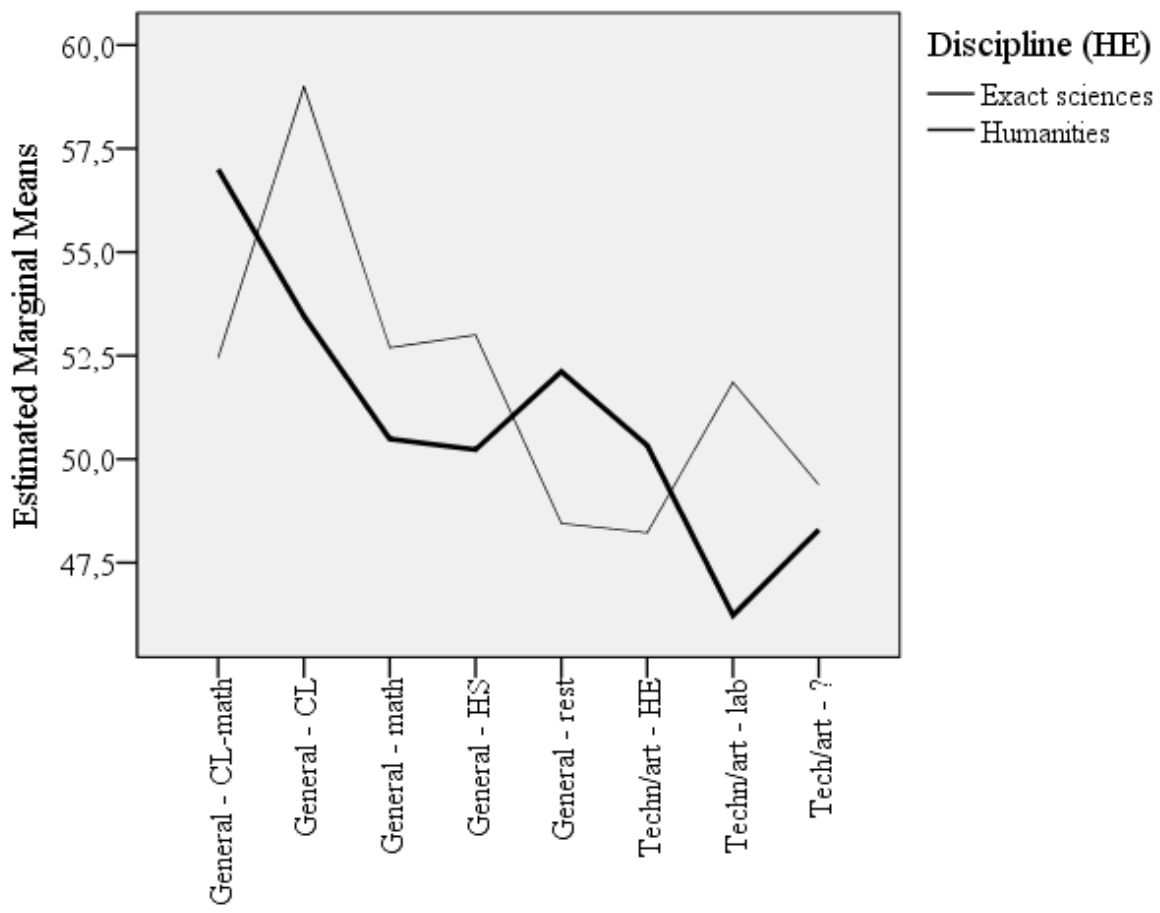

Field of study (SE)

Figure 1. Interaction effect of field of study (SE) and discipline (HE) on entrance CT performance

Table 3. Descriptive statistics of the interaction effect between field of study and discipline

\begin{tabular}{lll}
\hline Field of study (SE) & Discipline (HE) \\
\cline { 2 - 3 } & Exact sciences & Humanities \\
& $M(S D)$ & $M(S D)$ \\
\hline Academic - classical languages - mathematics & $52.44(1.80)$ & $57.00(2.79)$ \\
Academic - classical languages & $59.00(4.27)$ & $53.46(1.17)$ \\
Academic - mathematics & $52.69(2.73)$ & $50.49(1.75)$ \\
Academic - human sciences & $53.00(7.63)$ & $50.23(1.08)$ \\
Academic - rest category & $48.45(3.19)$ & $52.12(.72)$ \\
Technical/artistic - preparing for HE & $48.22(1.52)$ & $50.33(4.41)$ \\
Technical/artistic - preparing for the labour market & $51.86(2.12)$ & $46.23(.81)$ \\
Technical/artistic - not specified & $49.40(1.19)$ & $48.30(1.41)$ \\
\hline
\end{tabular}

b. Are there differences in growth based on SE and HE? 
The first analysis studies the influence of education form in SE and the two HE variables on the growth in CT during the first year of HE. Two main and two interaction effects are found. Firstly, the analysis reveals a main effect of education form in SE on the growth scores, $F(1,315)=6.30, p<.05$. Studens with an general SE background $(M=$ $5.03, S D=1.24)$ grow significantly more in CT than students with a technical/artistic SE background $(M=1.48, S D$ $=.68)$. Secondly, a main effect of programme type in HE is found, $F(1,315)=8.09, p<.01$. Students in a professional bachelor programme $(M=5.26, S D=1.30)$ show a significantly larger growth during the first year in $\mathrm{HE}$ than students in an academic bachelor programme $(\mathrm{M}=1.24, \mathrm{SD}=.56)$. Thirdly, there is an interaction effect between education form in SE and programme type in HE on the growth in CT during the first year of $\mathrm{HE}, F(1,315)$ $=6.90, p<.01$ (see Figure 2). The differences in growth between students with an general SE and a technical/artistic background are influenced by their programme type in HE. Students with an academic prior education show a much larger growth in professional bachelor programmes $(M=8.89, S D=2.42)$ than in academic bachelor programmes $(M$ $=1.16, S D=.54)$. Students with a technical/artistic background also grow more in professional bachelor programmes $(M=1.63, S D=.93)$ than in academic bachelor programmes $(M=1.33, S D=.98)$ but this difference is much smaller than for the general SE students. Fourthly, an interaction effect between all three of the independent variables is found, $F(1,315)=3.89, p=.05$ (see Figure 3a and 3b). Concerning students with an general SE background, this means that there is an interaction between programme type and discipline in HE. Students in the combination professional bachelor - exact sciences $(M=13.50, S D=4.74)$ grow more in CT than students in the combination professional bachelor - humanities $(M=4.29, S D=1.00)$, while academic bachelor students show a larger growth in combination with humanities $(M=2.11, S D=.74)$ than in combination with exact sciences $(M=.21, S D=.80)$. However, concerning students with a technical/artistic SE background, there is no interaction between programme type and discipline in HE. In both professional and academic bachelor programmes, students from the humanities show a larger growth than students from the exact sciences (see Table 4).

In the second analysis field of study in SE and the two HE variables are included as independent variables. The only significant effect that was revealed in this analysis is the main effect of programme type on the growth of CT, $F(1$, $284)=3.88, p=.05$. Students in a professional bachelor programme $(M=5.38, S D=1.09)$ show a significantly larger growth in CT during the first year of HE than students in an academic bachelor programme $(M=1.71, S D$ $=.92$ ).

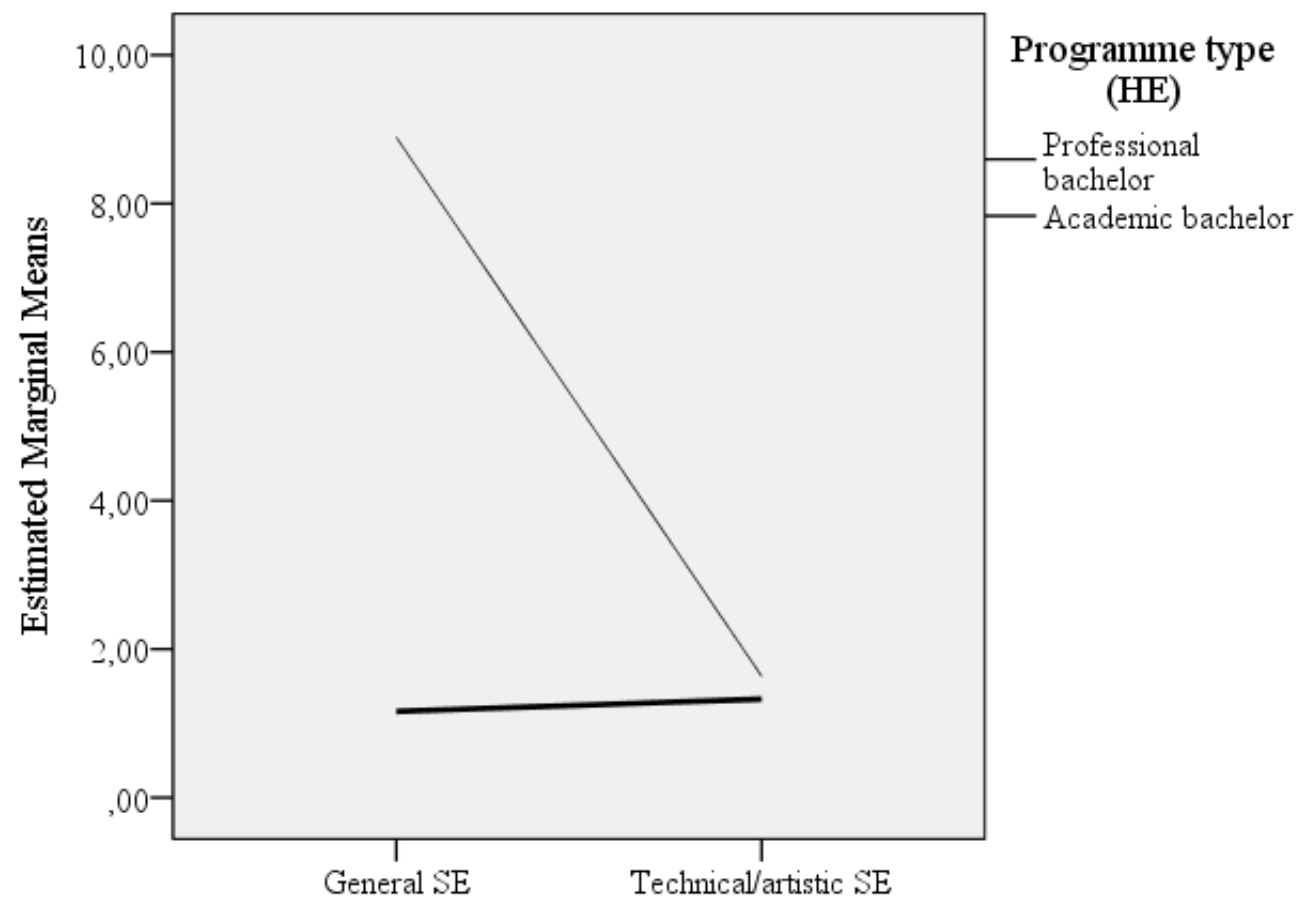

\section{Education form (SE)}

Figure 2. Interaction effect between education form (SE) and programme type (HE) on CT growth 


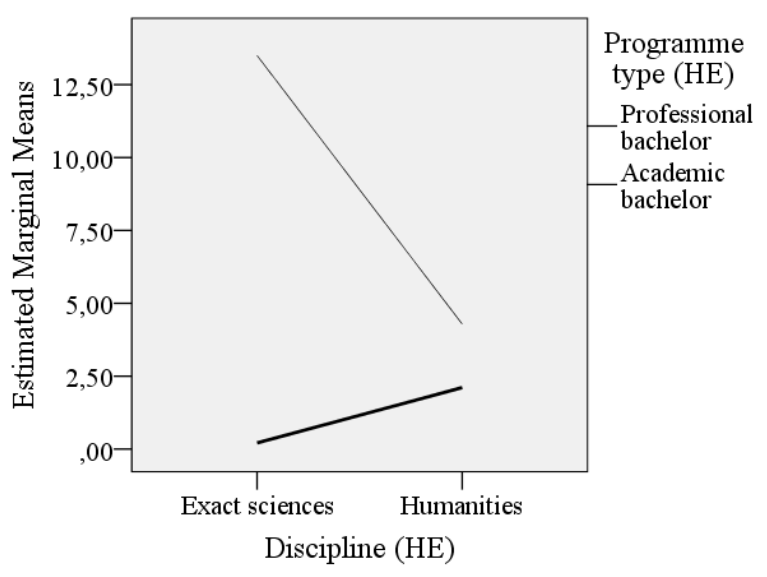

Figure 3a. Interaction effect of discipline (HE) and programme type (HE) on CT growth for students with a general SE background

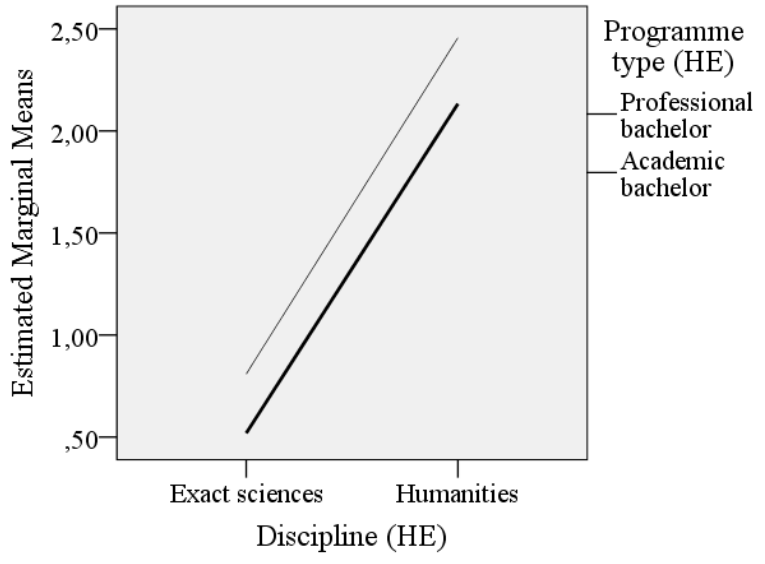

Figure 3b. Effect of discipline (HE) and programme type (HE) on CT growth for students with a technical/artistic SE background

Table 4. Descriptive statistics of the interaction effect between field of study, programme type and discipline

\begin{tabular}{llll}
\hline Education form (SE) & $\begin{array}{l}\text { Programme type } \\
(\mathrm{HE})\end{array}$ & Discipline (HE) & \\
\cline { 3 - 4 } & & Exact sciences & Humanities \\
\hline General SE & Professional bachelor & $13.50(4.74)$ & $4.29(1.00)$ \\
& Academic bachelor & $21(.80)$ & $2.11(.74)$ \\
\hline Technical/artistic SE & Professional bachelor & $81(1.46)$ & $2.46(1.13)$ \\
& Academic bachelor & $52(.93)$ & $2.13(1.73)$ \\
\hline
\end{tabular}

c. Are there differences in end performance based on SE and HE?

The mean score on the May administration is 52.20 and the standard deviation is 8.33 (see Table 2). The first analysis, in which education form in SE and the two HE variables are used as the independent variables, revealed one significant main effect and one significant interaction effect. Firstly, a main effect of education form on end CT performance in the first year of HE is found, $F(1,338)=14.15, p<.001$. Students with an general SE background $(M=54.70, S D=1.00)$ significantly outperform students with a technical/artistic background $(M=49.94, S D=.78)$. Secondly, an interaction effect between education form in SE and programme type in HE on CT at the end of the first year of $\mathrm{HE}$ is found, $F(1,338)=4.04, p<.05$ (see Figure 4). This means that the differences in CT performance between academic and technical/artistic SE students are influenced by their programme type in HE. Concerning students with an general SE background, professional bachelors $(M=56.27, S D=1.88)$ outperform academic bachelors $(M=53.14, S D=.64)$. Concerning students with a technical/artistic SE background, however, academic bachelors $(M=50.92, S D=1.17)$ outperform professional bachelors $(M=48.96, S D=1.04)$.

The second analysis, which consists of the independent variables field of study in SE and the two HE variables, could only reveal a main effect of field of study in SE on end CT performance, $F(8,303)=3.03, p<.01$. The Tukey post hoc test indicated that students from general SE - classical languages and mathematics $(M=60.36, S D=2.56)$ significantly outperform students with a prior education in technical/artistic SE - preparing for HE $(M=48.30, S D=$ $2.86)$, technical/artistic - preparing for the labour market $(M=51.80, S D=1.81)$ and technical/artistic SE - not specified $(M=49.69, S D=1.72)$. 


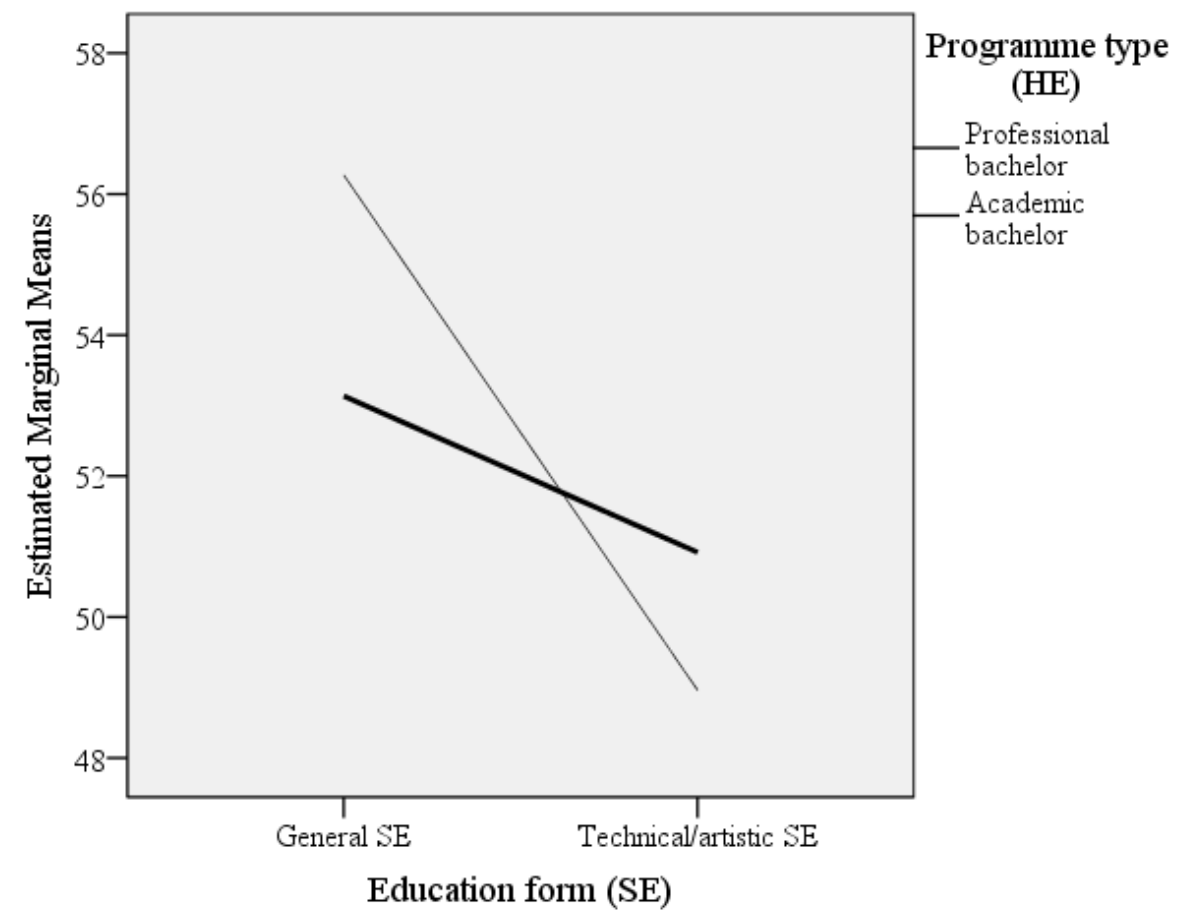

Figure 4. Interaction effect between education form (SE) and programme type (HE) on end CT performance

\section{Discussion}

Research question 1 examined the development in CT during the first year of HE. The average growth score amounts 1.91 points (or 0.26 standard deviations) and is significant at the .05 level. As expected the average growth is rather small. The small increase in CT that is found matches the results of previous research (Astin, 1993; Bers, McGowan \& Rubin, 1996; Giancarlo \& Facione, 2001; Hagedorn et al., 1999; Lehmann, 1963; McMillan, 1987; Miller, 1992; Saucier, 1995). Even though CT is considered to be an important educational goal (Halpern, 1993, 1998; Ku, 2009; Tsui, 2002), the impact of one year of HE on students' CT is rather small. A possible explanation for this finding is the idea that educators do not explicitly pursue CT in their instruction. Paul, Elder and Bartell (2003) investigated faculty in teacher education and found that, although the large majority $(89 \%)$ of the participants claimed that CT was a primary objective of their instruction, only $9 \%$ of the respondents indicated that they clearly teach for CT on a typical day in class. This finding might be caused by the idea that educators do not know how to provide appropriate instruction for CT. Although literature shows that CT can be taught and learned (Halpern, 1998), there is little consistency about which instructional approaches are the most effective in order to promote CT (McMillan, 1987; Pascarella \& Terenzini, 2005; Tsui, 1999). Another possible explanation for the small growth in CT is, as mentioned earlier, suggested by Arum and Roksa (2011). They argue that students are becoming more and more academically adrift and that universities do not pay enough attention to teaching. This explanation is however not necessarily valid for the Flemish situation. A third possible explanation for the small growth in CT is the idea that the first years in HE focus more on the reproduction of learning contents than on CT. Dutch research shows that first year exams usually hardly focus on students' use of critical, analytical and concrete processing strategies (Vermunt, 2005). Finally, these results could be caused by dropout of those students that would have shown a large growth if they would have continued their HE programme. An independent samples t-test was performed in order to check this explanation. There appears to be no significant difference in entrance performance between the students who dropped out $(M=$ $49.90, S D=8.05)$ and those who completed their first year of $\mathrm{HE}(M=50.54, S D=8.09), t(745)=-1.08, p=.28$, making this explanation questionable.

The aim of research question 2 was to investigate the influence of both SE and HE on CT in the first year of HE. Differences in entrance performance, in growth and in end performance were studied. Four main conclusions can be drawn. Firstly, students with a general SE background, who have a more academic profile, were expected to outperform technical/artistic SE students on CT both in the beginning and at the end of the first year of HE. 
According to the Matthew effect, they were also expected to show a larger growth in CT than technical/artistic SE students. These expectations were met by the results. The findings are consistent with the results of Lacante et al. (2001), Bellens (2011) and Smedts et al. (2011), who concluded that students from general SE have the highest success rates in HE. The present study shows that this difference is also applicable to CT in HE. Moreover, these results point out that the Matthew effect, which poses that the rich get richer and the poor get poorer (Stanovich, 1986), applies in the context of prior education and CT. Students from general SE, who have stronger entrance performances than their fellow students, show a larger growth in CT during the first year. The precise cause of the better entrance performance of general SE students is however unclear. Do academic fields of study in SE stimulate CT more than other education forms or do other characteristics of students who choose general SE play a role? Research has shown that many factors influence pupils' option choice in SE, e.g. gender, achievement, socioeconomic status, etc. (Pinxten, De Fraine, Van Den Noortgate, Van Damme \& Anumendem, 2012).

Secondly, students with a prior education in general SE - classical languages and/or mathematics were expected to outperform the other students with an general SE background, especially those who studied general SE - human sciences. These expectations were not met by the results. On the November administration the only significant differences that were found were the better performances of all academic fields of study in SE in comparison with technical/artistic SE - preparing for the labor market. No significant differences between the separate academic fields of study in SE were found. Furthermore, there were no significant differences in growth based on field of study in SE. As a consequence, also at the May administration there were no significant differences between the separate academic fields of study in SE. The literature that claims that fields of study with classical languages and/or mathematics lead to more academic success in HE (Bellens, 2010; Cooper et al., 2008, Janssens \& De Metsenaere, 2000; Lacante et al., 2001; Smedts et al., 2011) and that pupils from human sciences show a profile of academic performance that lies closer to technical SE pupils than to other general SE pupils (Lacante et al., 2001) cannot be generalized to CT. Possible explanations for the absence of differences in CT between academic fields of study in SE are the ideas that all these fields of study equally stimulate $\mathrm{CT}$, that in all these fields of study only little attention is paid to CT, or that background differences with an influence on CT are similar for all general SE students. This explanation is however questionable because Pinxten et al. (2012) showed that many background characteristics influence pupils' option choice in SE. A more plausible explanation for the absence of differences based on field of study in SE is the fact that the number of students in each category that was used in the present study is rather small (e.g. $n=26$ in general SE - classical languages and mathematics), which easily leads to uncertain results (Cohen, 1977).

Thirdly, on the November administration there is an interaction effect between field of study in SE and discipline in HE. Students with an educational background in general SE - classical languages and mathematics, general SE - rest category and technical/artistic SE - preparing for HE have higher entrance performances on CT if they choose a discipline from the humanities in HE. Students with another prior education perform better on the November administration if they choose exact sciences in HE. There are no differences in the growth or the May scores based on discipline in HE. Because the differences only exist in the entrance performance, they cannot be explained by instructional differences between the different disciplines in HE. This means that students' choice for a certain discipline, given their prior education, is related to their CT performance. It is remarkable that most combinations that lead to better CT performances are composed in an unexpected way. Most fields of study in SE that focus on mathematics and sciences (e.g. general SE - classical languages and mathematics, technical/artistic SE - preparing for HE) lead to higher CT performances in combination with HE disciplines from the humanities, while fields of study in SE that mainly focus on social and behavioral themes (e.g. general SE - human sciences, general SE classical languages, technical/artistic SE - preparing for the labour market) show higher CT performances when they are combined with HE disciplines from the exact sciences. Because definitions of CT include skills as self-regulation (Facione, 1990) and decision-making (Halpern, 1998), and dispositions as the suppression of impulsive activity, flexibility and open-mindedness (Halpern, 1998) it might be possible that better critical thinkers are more likely to choose a discipline in HE that is a less common path to follow based on their prior education. However, it should be remarked that this explanation cannot plainly be generalized to all students, because in the present study there are also exceptions on this rule (e.g. general SE - mathematics). It might be interesting for further research to investigate this explanation.

Finally, professional bachelor programmes lead to a larger growth in CT than academic bachelor programmes. There is also an interaction effect between education form in SE and programme type in HE. The difference between professional and academic bachelors is much larger for students with a general SE background than for students with a technical/artistic SE background, but for both education forms professional bachelor programmes lead to the 
highest CT performances. As a consequence, on the May administration professional bachelor students with a general SE background outperform academic bachelor students with the same prior education. For the students with a technical/artistic background, the academic bachelors still slightly outperform the professional bachelors. The reason why professional bachelors show a larger growth than academic bachelors is unclear. Arum and Roksa (2011) state that universities do not prioritize undergraduate learning because they are expected to accomplish many other tasks. This might be an explanation for the smaller growth in CT in academic than in professional bachelors. It should be noted, however, that Arum and Roksa's conclusion is not necessary suitable for the situation in Flanders. Furthermore, it might be possible that the smaller student groups in professional bachelors allow educators to more systematically pay attention to CT.

\section{Conclusion}

Firstly, the results of this study indicate that the growth in CT during the first year of HE is on average small. Secondly, the influence of SE and HE on CT during the first year of HE was studied. Concerning education forms in SE, the Matthew effect was confirmed in the present study. Students with a general SE background, who have a higher entrance performance than students with a technical/artistic SE background, also show a larger growth in CT during the first year of HE. The Matthew effect did however not appear when comparing students based on their field of study in SE. Furthermore, the present study revealed that the influence that fields of study in SE have on CT at the start of HE is different based on the discipline that students choose in HE. Better critical thinkers seem to make other educational choices than poorer critical thinkers. Finally, students in a professional bachelor programme grow more in CT during the first year of higher education than students in an academic bachelor programme.

The results of this study indicate the importance of the initial situation of students for CT instruction in HE. Given the diversity among students with respect to relevant variables, it seems clear that differentiation also with respect to teaching CT is essential.

\section{References}

Arum, R. \& Roksa, J. (2011). Academically adrift: Limited learning on college campuses. Chicago: The University of Chicago Press.

Astin, A. W. (1993). What matters in college. San Francisco: Jossey-Bass.

Bailin, S., Case, R., Coombs, J. R. \& Daniels, L. B. (1999). Conceptualizing critical thinking. Journal of Curriculum Studies, 31, 285-302. http://dx.doi.org/10.1080/002202799183133

Bellens, K. (2010). Secundaire vooropleiding als determinant van studiesucces in het hoger onderwijs: een exploratie op basis van de LOSO-databank [Secondary prior education as a determinant of academic success in higher education: an exploration based on the LOSO-database] (Unpublished master dissertation). Katholieke Universiteit Leuven, Faculteit Psychologie en Pedagogische Wetenschappen, Centrum voor Onderwijseffectiviteit en -evaluatie.

Bers, T., McGowan, M., \& Rubin, A. (1996). The disposition to think critically among community college students: The California Critical Thinking Disposition Inventory. Journal of General Education, 45, 197-223.

Biglan, A. (1973). The characteristics of subject matter in different academic areas. Journal of Applied Psychology, 57, 195-203. http://dx.doi.org/10.1037/h0034701

Bok, D. C. (2006). Our underachieving colleges: A candid look at how much students learn and why they should be learning more. Princeton: Princeton University Press.

Cohen, J. (1977). Statistical power analysis for the behavioral sciences (revised edition). New York: Academic Press, Inc.

Deprez, N. (2003). Studiekeuze in het secundair onderwijs en slaagkansen in het hoger onderwijs [Educational choice in secondary education and success rates in higher education] (Unpublished master dissertation). Katholieke Universiteit Leuven, Faculteit Economische en Toegepaste Economische Wetenschappen, Departement Toegepaste Economische Wetenschappen.

Ennis, R. H., Millman, J., \& Tomko, T. N. (2005). Cornell critical thinking test (5th ed.). Pacific Grove, CA: Midwest Publications.

Erwin, T. D. \& Sebrell, K. W. (2003). Assessment of critical thinking: ETS's Tasks in Critical Thinking. The Journal of General Education, 52, 50-70. http://dx.doi.org/10.1353/jge.2003.0019

Facione, P. A. (1990). CT: A statement of expert consensus for purposes of educational assessment and instruction. 
Research findings and recommendations. Retrieved from ERIC database. (ED315423).

Field, A. (2005). Discovering statistics using SPSS (second edition). London: Sage.

Gadzella, B. M. \& Masten, W. G. (1998). Critical thinking and learning processes for students in two major fields. Journal of Instructional Psychology, 25, 256-262.

Giancarlo, C. A. \& Facione, P. A. (2001). A look across four years at the disposition toward critical thinking among undergraduate students. The Journal of General Education, 50, 29-55. http://dx.doi.org/10.1353/jge.2001.0004

Hagedorn, L. S., Pascarella, E. T., Edison, M., Braxton, J., Nora, A. \& Terenzini, P. T. (1999). Institutional context and the development of critical thinking: A research note. The Review of Higher Education, 22, 265-285. http://dx.doi.org/10.1353/rhe.1999.0010

Halpern, D. F. (1993). Assessing the effectiveness of critical thinking instruction. The Journal of General Education, 50, 238-254. http://dx.doi.org/10.1353/jge.2001.0024

Halpern, D. F. (1998). Teaching critical thinking for transfer across domains: Dispositions, skills, structure training, and metacognitive monitoring. American Psychologist, 53, 449-455. http://dx.doi.org/10.1037/0003-066X.53.4.449

Halpern, D. F. (1999). Teaching for critical thinking: Helping students develop the skills and dispositions of a critical thinker. New Directions for Teaching and Learning, 80, 69-74. http://dx.doi.org/10.1002/tl.8005

Halpern, D. F. (2007). Halpern critical thinking assessment using everyday situations: Background and scoring standards. Claremont, CA: Claremont McKenna College.

Hermans, D. J., Opdenakker, M. \& Van Damme, J. (2003). Ongelijke kansen in het secundair onderwijs in Vlaanderen. Een longitudinale analyse van de interactie-effecten van geslacht, etniciteit en socio-economische status op de bereikte onderwijspositie met aandacht voor het effect van de school: een vervolg [Unequal chances in secondary education in Flanders. A longitudinal analysis of the interaction effects of sex, etnicity and socio-economic status on the attained educational position with attention to the effect of school: a follow-up]. Retrieved February 23, 2012, from http://www.steunpuntloopbanen.be/rapporten/LOA-rapport_07.pdf

Janssens, R. \& De Metsenaere, M. (2000). Een maat voor niets? Zin en onzin van een universitaire selectieproef [A measure for nothing? Sense and nonsense of a university selection test]. Brussel: VUBpress.

$\mathrm{Ku}$, K. Y. L. (2009). Assessing students' critical thinking performance: Urging for measurements using multi-response format. Thinking Skills and Creativity, 4, 70 - 76. http://dx.doi.org/10.1016/j.tsc.2009.02.001

Ku, K. Y. L. \& Ho, I. T. (2010). Dispositional factors predicting Chinese students' critical thinking performance. Personality and Individual Differences, 48, 54-58. http://dx.doi.org/10.1016/j.paid.2009.08.015

Lacante, M., De Metsenaere, M., Lens, W., Van Esbroeck, R., De Jaeger, K., De Coninck, T., Gressens, K., Wenselaer, C., \& Santy, L. (2001). Drop-out in het hoger onderwijs: onderzoek naar achtergronden en motieven van drop-out in het eerste jaar hoger onderwijs [Drop-out in higher education: research into backgrounds and motives of drop-out in the first year of higher education]. Brussel: Ministerie van de Vlaamse gemeenschap, Departement Onderwijs.

Lehmann, I. J. (1963). Changes in critical thinking, attitudes, and values from freshmen to senior years. Journal of Educational Psychology, 54, 305-315. http://dx.doi.org/10.1037/h0045302

Li, G., Long, S. \& Simpson, M. E. (1999). Self-perceived gains in critical thinking and communication skills: Are there disciplinary differences? Research in Higher Education, 40, 43-60. http://dx.doi.org/10.1023/A:1018722327398

McMillan, J. H. (1987). Enhancing college students' critical thinking: A review of studies. Research in Higher Education, 26, 3-29. http://dx.doi.org/10.1007/BF00991931

Miller, D. A., Sadler, J. Z. \& Mohl, P. C. (1993). Critical thinking in preclinical course examinations. Academic Medicine, 68, 303-305. http://dx.doi.org/10.1097/00001888-199304000-00020

Miller, M. A. (1992). Outcomes evaluation: Measuring critical thinking. Journal of Advanced Nursing, 17, 1401-1407. http://dx.doi.org/10.1111/j.1365-2648.1992.tb02810.x

Ministry of the Flemish community (2005). Education in Flanders: The Flemish educational landscape in a nutshell. [Brochure]. Brussels: Agency for Educational Communication. 
Pascarella, E. T., Blaich, C., Martin, G. L. \& Hanson, J. M. (2011). How robust are the findings of Academically Adrift? Change, 43, 20 - 24. http://dx.doi.org/10.1080/00091383.2011.568898

Pascarella, E. T. \& Terenzini, P. T. (2005). How college affects students: A third decade of research, Vol. 2. San Francisco: Jossey-Bass.

Paul, R. (1992). Critical thinking: What, why, and how. New Directions for Community Colleges, 1992, 3 - 24. http://dx.doi.org/10.1002/cc.36819927703

Paul, R., Elder, L. \& Bartell, T. (2003). Study of 38 public universities and 28 private universities to determine faculty emphasis on critical thinking in instruction (executive summary). Retrieved March 27, 2013, from the Critical Thinking Consortium Web site: http://www.criticalthinking.org/schoolstudy.htm

Pinxten, M., De Fraine, B., Van Den Noortgate, W., Van Damme, J. \& Anumendem, D. (2012). Educational choice in secondary school in Flanders: The relative impact of occupational interests on option choice. Educational research and evaluation, 18, 541 - 569. http://dx.doi.org/10.1080/13803611.2012.702991

Rombaut, K. (2006). Determinanten van de differentiële slaagkansen in het hoger onderwijs [Determinants of differential success rates in higher education]. Retrieved May 29, 2013, from http://webh01.ua.ac.be/csb/docs/20071106131351qttp.pdf

Saucier, B. L. (1995). Critical thinking skills of baccalaureate nursing students. Journal of Professional Nursing, 11, 351-157. http://dx.doi.org/10.1016/S8755-7223(95)80054-9

Scott, J. N. \& Markert, R. J. (1994). Relationship between critical thinking skills and success in preclinical courses. Academic Medicine, 29, 920-924. http://dx.doi.org/10.1097/00001888-199411000-00015

Scott, J. N., Markert, R. J. \& Dunn, M. M. (1998). Critical thinking: Change during medical school and relationship to performance in clinical clerkships. Medical education, 32, 14 - 18 . http://dx.doi.org/10.1046/j.1365-2923.1998.00701.x

Smedts, D., Van Landeghem, G. \& Van Damme, J. (2011). Een bachelordiploma behalen in het Vlaams hoger onderwijs: een verkennend onderzoek betreffende de generatiestudenten van 2004-2005 en 2005-2006 [Obtaining a bachelor's degree in Flemish higher education: an exploratory study concerning the generation students of 2004-2005 and 2005-2006]. Retrieved February 17, 2012, from https://lirias.kuleuven.be/bitstream/123456789/325488/1/SSL-rapport36_BachelordiplomaGeneratiestudenten\% 5B1\%5D.pdf

Stanovich, K.E. (1986). Matthew effects in reading: Some consequences of individual differences in the acquisition of literacy. Reading Research Quarterly, 21, 360-407. doi: 10.1598/RRQ.21.4.1

ten Dam, G. \& Volman, M. (2004). Critical thinking as a citizenship competence: Teaching strategies. Learning and Instruction, 14, 359-379. http://dx.doi.org/10.1016/j.learninstruc.2004.01.005

Terenzini, P. T., Springer, L., Pascarella, E. T. \& Nora, A. (1995). Influences affecting the development of students' critical thinking skills. Research in Higher Education, 36, 23-39. http://dx.doi.org/10.1007/BF02207765

Tsui, L. (1999). Courses and instruction affecting critical thinking. Research in Higher Education, 40, 185-200. http://dx.doi.org/10.1023/A:1018734630124

Tsui, L. (2002). Fostering CT through effective pedagogy: Evidence from four institutional case studies. The Journal of Higher Education, 73, 740-763. http://dx.doi.org/10.1353/jhe.2002.0056

Verburgh, A., François, S. \& Elen, J. (2012). The development of critical thinking in first year educational sciences students. Paper presented at European Conference on Educational Research 2012.

Verburgh, A., François, S., Elen, J., \& Janssen, R. (2013). The assessment of critical thinking critically assessed in higher education: A validation study of the CCTT and the HCTA. Manuscript under review.

Verburgh, A., Schouteden, W., Elen, J. (2012). Patterns in the prevalence of research-related goals in higher education programmes. Teaching in Higher Education, art.nr. 10.1080/13562517.2012.719153, 1-13.

Vermunt, J. D. (2005). Relations between student learning patterns and personal and contextual factors and academic performance. Higher Education, 49, 205 - 234. http://dx.doi.org/10.1007/s10734-004-6664-2

Walberg, H. J. \& Tsai, S. (1983). Matthew effects in education. American Educational Research Journal, 20 , 359-373. http://dx.doi.org/10.2307/1162605 